\title{
The Evolution of the Intellectual Property Management Strategy of an Emerging Multinational: Learning the Purpose of Patenting and Scientific Publications
}

\author{
Tracy Bromfield and Helena Barnard
}

\begin{abstract}
The transition from developing country technology firm to true multinational requires both an upgrading of the underlying capability base and an understanding of the purpose of IP management. Through a detailed case study of Sasol, a leading R\&D firm from South Africa, this paper tracks the coevolution of IP management with technological advancement amid the constraints of the developing country context. Using interviews, annual reports, patent, and scientific publication data, this study suggests that the value of formal IP extends beyond appropriation of own capabilities. Importantly, patents and publications also serve to signal capabilities in an attempt to gain legitimacy among peers. Fundamentally, IP management involves a social process, where firms learn to manage the sharing of key capabilities-with the attendant competition/cooperation tension-to peers.
\end{abstract}

Index Terms - Intellectual property management, managing innovation in emerging economies, scientific publications, South Africa, technology accumulation patents.

\section{INTRODUCTION}

$\mathbf{F}$ ORMALIZED intellectual property protection (IPP) is the norm among multinational corporations (MNCs) in the developed world. However, IPP in the developing world has long been a contested topic [1], [2] and is sometimes seen as an exclusionary measure that makes it hard for less advanced firms to get a foothold in the global economy. Murmann [3], in his study of the emergence of the chemical industry, provides insight into the simultaneous distrust (mainly in the developing world) and valuing (mainly in the developed world) of formalized IP regimes: For firms with little of their own IP, formal protection is a barrier to their upgrading - those firms stand to benefit from freely imitating existing technologies. But once firms have developed their own IP, a formalized IP management regime allows them to reap the benefits of their technological advances not only within, but also outside the firm. In other words, the emergence of an IPP strategy is both an enabler and an indicator of technological advance.

Manuscript received March 28, 2008; revised October 15, 2008 and April 1, 2009. First published September 18, 2009; current version published January 20,2010. Review of this manuscript was arranged by Department Editor C.-C. Hang.

T. Bromfield was with the Gordon Institute of Business Science, University of Pretoria, Johannesburg, South Africa. She is currently affiliated with Sasol Technology R\&D, Sasolburg, South Africa (e-mail: tracy.bromfield@sasol.com).

H. Barnard is with the Gordon Institute of Business Science, University of Pretoria, Johannesburg, South Africa (e-mail: barnardh@gibs.co.za).

Color versions of one or more of the figures in this paper are available online at http://ieeexplore.ieee.org.

Digital Object Identifier 10.1109/TEM.2009.2025493
The fact that emerging players have to function in the global economy from the outset further complicates the dual role of formal IPP as both a barrier and an enabler of technological advancement. Firms with limited technological expertise need extensive learning to operate in a world with a defined IP infrastructure. This paper investigates how a firm with such limited technological expertise and no IP strategy becomes a firm with proprietary technology and a defined IP strategy. Looking at the case of Sasol, a South African industrial chemicals firm, we present evidence that two separate but related processes need to take place for firms to make that transition: First is the welldocumented need to develop a depth of technological expertise. Second is the development of an understanding of the purpose and value of communicating IP. In this latter process, the actual technological expertise is less important. Instead the purpose of establishing formal IP is to establish a presence in the relevant community of firm and university researchers, with the ultimate goal to obtain access to the knowledge of other parties. The mechanisms can be quite simple and informal, e.g., to be invited to a relevant conference on the basis of prior performance in the field, but can also be complex and formal-e.g., by forcing rivals into negotiations about competing technologies.

The process by which firms disclose some of their most important technology (also to their competitors) with the purpose of gaining reciprocal access to the knowledge of their peers is social as much as technological. This study focuses on the first, social learning process-how firms learn what the potential gains of formalized IP are, what the associated costs are, and how to find the optimal balance between costs and benefits.

\section{LITERATURE REVIEW}

This study focuses on how a firm makes the transition from developing country player to a true MNC in terms of its capability base in general, and patenting behavior in particular. The prior work on firm upgrading tends to focus on the Asian Tigers, and particularly South Korea, e.g., Hobday [4], Kim [5], Lautier [6], Lee [7], [8], and Perrin [9]. Work on Latin America includes contributions by Dutrénit [10] and Figueiredo [11], [12].

Certain common themes emerge from these works. Initially, most of the technological upgrading efforts of firms are directed at assimilating the technologies from more advanced countries. Interaction with foreigners, whether through increased foreign competition or through good relationships with foreign suppliers 
or customers, plays an important role in enabling the upgrading. However, local efforts of the developing country firm are central. Moreover, the local contribution is not limited to work by and within the firm, but is shaped by a supportive local context. For example, political instability has been shown to have a negative effect on capability upgrading, especially by researchers of Latin America [10]. Finally, evidence consistently suggests that the development and exploitation of own technology is a milestone event in becoming a true MNC.

But although many studies investigate the evolution of R\&D, there has thus far been no focused investigation of the capacity to formally manage IP. Although these two processes coevolvefirms become more aware of the value of IP as they develop more valuable technologies - the capabilities to manage IP are not the same as those needed to create IP. To give a concrete example: It is necessary to understand chemistry to create new gasification knowledge, whereas an understanding of law and economics is needed to manage that new intellectual property. It is therefore important to identify the purpose of IP management, as well as to choose the most appropriate vehicle (e.g., patenting, scientific publication, or even secrecy) for realizing that particular purpose.

Establishing formal IP can take place through patenting or scientific publications. Early work suggested that technological development (represented by patenting activity) and scientific advances (measured through scientific publications) operate in tandem but largely independently [13]. However, later work demonstrates that there is a mutually beneficial relationship between the two, and that the strengthening of the relationship between patenting and scientific publication is associated with higher levels of economic development [14]. Some form of formal IP process has been in existence for centuries, and scholars who examine the historical evolution of IP systems consistently point out the correlation between higher levels of development and formal IPP [15], [16]. However, IP plays an ambiguous role in emerging economies. This can be related back to firms' technological capacity-Murmann [3] documents that a lax IP regime favors parties with limited own IP to protect, because those parties benefit most from being able to appropriate the knowledge of others.

Patenting encourages innovation by requiring full public communication about a new invention in exchange for temporary monopoly rights. While firms exploit their temporary monopoly, competitors can use the information disclosed in the patent document to guide their own R\&D. Innovation at a societal level is therefore argued to benefit from patenting. However, IPP can also act as an exclusionary measure for weaker partners (like those from developing countries). This dual effect reflects typical concerns about the purpose of formal IP regimes. In a review of the controversy surrounding patenting in the nineteenth century, Machlup and Penrose [17] identify recurring arguments against the use of IP. Their study is usefully contextualized by more recent work on the theoretical justification of patenting by Mazzoleni and Nelson [18]. Machlup and Penrose document a concern about the validity of property rights for ideas and resistance to the very idea of IP, a concern that has largely disappeared from the contemporary debate.
However, regarding the incentives offered by patenting, the terms of the debate have hardly changed. A belief that emerged in the nineteenth century and is still held today is that inventors are entitled to just reward, tempered by a concern that the temporary monopoly offered by patenting may not be the best way to reward invention. This concern is heightened when considering the issue at the societal level, where the social costs of patenting could potentially outweigh the social benefits. There is likewise a tension between the perceived benefits of sharing information compared to keeping it secret, and-because IP per definition deals with emerging knowledge — no clear idea of what the optimal balance between communication and secrecy should be.

At the firm level, the issue of appropriating the benefits of innovation is critical. However, secrecy, investment in brand building, and exploiting a first-mover advantage (e.g., through lead times and learning curve effects) are all highly effective mechanisms to appropriate the benefits of innovation [19]. To make an informed decision about whether to reap the benefits of a new invention through one of these mechanisms or through formal IP protection, a new patentor has to develop an understanding of the costs of communicating information about new technologies - and not only the direct costs, but particularly the costs of sharing previously proprietary information with competitors.

This necessitates serious consideration of the other parties that may be interested in a newly disclosed technology. The knowledge creators in an industry tend to be informally organized into a type of "club" or "knowledge network" of specialists from firms and universities who work in the same broad field. Those specialists have the necessary knowledge to appreciate a new technology and to potentially contribute to the further advancement of that technology. On the other hand, they are very often also competitors, interested in a technology not for the sake of technology itself, but as a potential tool for developing their own competitiveness.

This creates a tension between appropriation and sharing within the knowledge network, and patents play an important role in managing that tension. Firstly, patents can be used to signal competence. Although knowledge networks operate informally, they have real entry requirements, and patents are used as evidence that a firm should be taken seriously as a member of and contributor to that community. Secondly, because patents provide codified evidence of capability, they can serve as bargaining chips among other knowledge creators [20], [21]. Experienced patentors often use their own patents to negotiate access to the technologies of their competitors.

In addition, there is a difference in the purpose of patenting in "discreet" and "complex" industries. In "discreet" industries, of which the chemicals industry is a typical example, patents are used to block rival developments [22] and to build a "fence" around an invention, thus increasing the value of the invention as a whole [23]. In "complex" industries like semiconductors, patents form what is best described as a "thicket," and patents are typically used to force rivals into negotiations about shared knowledge. This implies that a firm has to understand not only its own goals with patenting, but also how the industry uses IP. 
In addition, Reitzig points out that "fences" may under certain conditions turn into "thickets," suggesting that the evolution of technologies may become more interdependent over time. For a firm without previous IP management experience, defining an appropriate IP strategy is made even harder by the fact that the very purpose of IP in the industry continues to evolve.

To some extent the purpose of patenting is very similar to the purpose of publishing in scientific publications: Both signal the existence of knowledge assets. However, the purpose of scientific publications is never to appropriate knowledge for direct gain. Instead, journal articles serve as currency for the exchange of knowledge within the scientific community [24]. Thus, scientific publications strengthen the reputation of the firm as an innovator in its field [25] and serve as an important precursor for establishing research partnerships [26]. These signals of competence are arguably particularly important for a firm that is not (yet) known for its technological capabilities, e.g., from a developing country.

The underlying purpose of formal IP is consistently to establish a presence in the relevant community of firm and university researchers, with as ultimate goal to obtain access to the knowledge of other partners. The mechanisms can be quite simple and informal, e.g., feedback from reviewers about a proposed article or patent, or much more complex and formal, e.g., as the basis for a proposed joint venture. However, the way in which experienced firms use IPP as a mechanism for an orderly exchange of capabilities contrasts sharply with the haphazard pattern of patenting typical in developing countries. da Motta e Albuquerque [27] documents that developing countries have a much larger share of patenting by individuals, with little firm involvement and a lack of continuity in patent activity. In addition, interfirm technological division or specialization is limited. It is clear that a developing country firm has to go through an extensive learning process, not only with regard to the technology it produces, but also in terms of how to best deploy formal IPP mechanisms to optimally benefit from its technology. This study documents how that learning process takes place.

\section{Methodology}

The study looks at the case of Sasol, the only South African firm on United Nations Council for Trade and Development's (UNCTAD's) list of leading R\&D spenders (516th worldwide), with an R\&D spend of $\$ 91 \mathrm{~m}$ in 2003 [28]. South Africa is a middle-income country that relies heavily on foreign sources of new technology, but was (especially because of anti-Apartheid sanctions) long isolated from the global economy. In fact, many of the leading developing countries [e.g., Brazil, Russia, India, and China (BRICs) and European transition economies] have followed isolationist policies in the second half of the twentieth century, and only fairly recently started to reenter the global economic arena. Their policies ranged from mildly isolationist, e.g., "dependencia" thinking in Latin America and the Gandhian notion of "self sufficiency" in India, to policies that were more militantly isolationist, e.g., the mid-twentieth century communism of the Soviet Union and China. However, all had the consequence that countries were somewhat disconnected from technology developments in the rest of the world. Especially given the rise of globalization, managing the (re-)entry and participation in global knowledge networks has become a key component of managing innovation in developing countries.

Sasol's origins lie in the German Fischer-Tropsch (FT) process for generating fuel from coal and gas, and it has from the outset been a science-based firm, where technology creation is key to competitiveness. As a chemicals firm it is also in an industry where intellectual property protection, especially patenting, has been found to be of particular importance [29]. The firm was founded in 1950, and a formal R\&D function created in 1957. The Sasol data are available over the length of the firm's history. We interview key players in the IP management process of Sasol and review Sasol's patents, scientific publications, internal publications, and annual reports over a 50-year period (1955-2005) to track how the firm developed and deepened its understanding of the costs and benefits of patenting.

Patents and scientific publications are often used as proxies for technological advances. However, this study argues that an understanding of the purpose of patenting and scientific publications happens in concert but separately from technological capacity, and we therefore use an alternative indicator of technological competency. We discuss the development of new synthetic fuel reactors as milestones in the evolution of Sasol's ability and effectiveness in its core technology, transforming coal into fuels and chemicals. Using that indicator, the Sasol history can be divided into five eras (see Table I), initially corresponding to the development of different plants and in the last period to the decision to internationalize.

Sasol had no formal IP function or strategy for the bulk of its history and limited formal IP_-Sasol filed its first patent only in 1968. Because important technology accumulation and development took place in its early decades, and because a depth of technological expertise is important to support patenting, the paper briefly reviews all five periods to document the technologies and processes that were in place by the time that Sasol started to formalize IP management. However, the study emphasizes the last two eras in Sasol's history, where IP management was substantially advanced.

In addition to simple counts to determine the extent of formal methods of IP, we estimate the quality of patents and publications. The value of patents is measured through the use of their forward citations, a generally recognized indicator of their usefulness as sources of innovation [30]. In the case of scientific publications, the average impact factor of the journal is used as indicator. Journal impact factors are a measure of the frequency of citation of articles published in a specific journal. They are often used as a proxy for the relative importance of a journal to a particular field and have proven to be reliable indicators of long-term influence in finance and economics [31], as well as in science [32].

The measure is not without problems. One concern with the use of journal impact factors is that impact factors can vary substantially year to year. To overcome this concern, we report an average over a five-year period. In her fine-grained study Hicks [33] documents challenges associated with cocitation analysis, while Seglen [34] argues that journal impact 
TABLE I

Technological ERAS IN SASOl From Founding Till 2005

\begin{tabular}{|c|c|}
\hline Era & Achievements \\
\hline $\pm 1950-1975 \quad 1^{\text {st }}$ (Synthol) era & $\begin{array}{ll}\text { - } & \text { German Arge reactor or Low-Temperature } \\
\text { Fischer-Tropsch process replicated } \\
\text { - } \\
\text { Kellogg reactors or the High-Temperature } \\
\text { Fischer-Tropsch process commercially developed }\end{array}$ \\
\hline $\pm 1976-1985 \quad 2^{\text {nd }}$ (Secunda) era & $\begin{array}{l}\text { - Fourfold upscaling of Synthol-based plant in each } \\
\text { of Sasol II and Sasol III }\end{array}$ \\
\hline $\pm 1986-19903^{\text {rd }}\left(\mathrm{SAS}^{\mathrm{TM}}\right)$ era & $\begin{array}{l}\text { - } 16 \text { existing reactors replaced with } 8 \mathrm{SAS}^{\mathrm{TM}} \\
\text { reactors with lower capital cost, increased } \\
\text { flexibility, lower operating costs and greater } \\
\text { capacity that the preceding reactors }\end{array}$ \\
\hline $\pm 1991-2000 \quad 4^{\text {th }}\left(\mathrm{SPD}^{\mathrm{TM}}\right)$ era & $\begin{array}{l}\text { - } \mathrm{SPD}^{\mathrm{TM}} \text { reactor with six times the capacity of } \\
\text { German Arge reactors } \\
\text { Diversification into higher value chemicals: n- } \\
\text { butanol, anode coke, ethylene recovery, } \\
\text { propylene and polypropylene plants }\end{array}$ \\
\hline $\begin{array}{ll} \pm 2001-2005 & 5^{\text {th }} \text { (Globalization) } \\
\text { era }\end{array}$ & $\begin{array}{l}\text { - Acquisition of German Condea } \\
\text { - Research partnerships with University of Twente } \\
\text { (Netherlands) and St Andrew's in Scotland }\end{array}$ \\
\hline
\end{tabular}

factors are an indication only of an "overall view" and not useful for evaluating individual research. However, because the reputations of journals are widely known, journal impact factors are a good measure of how the members of the relevant community will assess the likely (future) contributions of researchers publishing in a journal of that perceived caliber. Because our interest is not in the technological advancement of Sasol per se, but rather in how Sasol learned to use its IP to obtain access to the knowledge of other partners (e.g., by learning to manage the tension between cooperation and competition), we look at impact factors at the journal rather than individual level.

By global standards Sasol has a small patent portfolio. The entire portfolio of patent applications filed or acquired by the Sasol Group of Companies during the 50 years period from 1955 to 2005 amounted to 835 patent applications filed in 95 countries worldwide. Especially, when considered per era the number of patents is small and only limited statistical analysis is possible. The study therefore makes use of descriptive statistics.

\section{RESULTS}

\section{A. First Forays in IP: The Synthol Era ( $\pm 1950-1976)$}

The very long initial period in the history of Sasol served as a type of "incubation" period. Sasol was founded with a strong nationalist orientation with the aim of improving South Africa's energy self-sufficiency. But like other developing country firms, e.g., from South Korea [35], [36] it lacked the local capacity base to execute its mission and strongly relied on external sources of expertise. Indeed, the company's early efforts were focused on transplanting foreign technology to South Africa.

Sasol drew extensively on international networks to develop the skills of its own people, e.g., by using German and American technicians and engineers to commission the fuels-from-coal reactors. The Kellogg (high-temperature Fischer-Tropsch, HTFT) reactor had not been built on commercial scale before. In 1957, after researchers from Germany, Great Britain and USA, including contractors from M.W. Kellogg and an American expert "of world repute on catalysis" [37] all proved unable to resolve the problems experienced during commissioning, a formal R\&D department was established. Researchers made significant changes to the original Kellogg design, culminating in the proprietary Sasol Synthol circulating fluidized bed reactor technology [49].

In this era, Sasol invested little in the codification of knowledge, and what was done reflects an internal orientation. For example, research reports (except when written by or for foreigners) were written in a local language, Afrikaans, and no attempts were made to publish peer-reviewed research. This was not because Sasol's research was weak. The fact that Sasol's reactors were operational and (by 1960) profitable provides perhaps the most concrete evidence of the quality of the technology. When a greater awareness developed about the value of participating in global knowledge networks, research results from this period still proved to be publishable. For example, a number of peer-reviewed papers on the development of Sasol's FT technology (drawing on findings from the early years) were published from 1982 onward.

Sasol in this era gave no thought to IPP as a strategic dimension of its business and relied on the notion that its operations were closely guarded secrets, and that knowledge was vested in a small collection of people, not documents. For instance, chemical ingredients were coded so that plant operators could not decipher the recipe for producing the catalyst. Initially, any form of external publication was eschewed because of the risk of divulgence. Then, with the encouragement of foreign employees, the first steps in patenting took place. Sasol's first patent was filed in South Africa only in 1968 and reflects the type of experimentation documented in other developing country contexts [27] rather than a response to a business need. Inexperienced patentors do not operate with a clear understanding of the goals and purposes of patenting, and patenting often results from a "me-too" mindset. The patents that were granted in the period 1971-1975 were generally filed in areas without strategic economic or technological importance, like the so-called 
TABLE II

SASOl Publications in PeER-REviewed Journals

\begin{tabular}{|c|c|c|c|c|c|c|c|c|}
\hline & $\begin{array}{l}1966- \\
1970\end{array}$ & $\begin{array}{l}1971- \\
1975\end{array}$ & $\begin{array}{l}1976- \\
1980\end{array}$ & $\begin{array}{l}1981- \\
1985\end{array}$ & $\begin{array}{c}1986- \\
1990 \\
\end{array}$ & $\begin{array}{l}1991- \\
1995\end{array}$ & $\begin{array}{l}1996- \\
2000\end{array}$ & $\begin{array}{l}2001- \\
2005\end{array}$ \\
\hline & \multicolumn{2}{|c|}{$\begin{array}{l}\text { (final stage of) } \\
\text { Synthol era }\end{array}$} & \multicolumn{2}{|c|}{ Secunda era } & $\begin{array}{c}\text { SAS }^{\mathrm{TM}} \\
\text { era }\end{array}$ & \multicolumn{2}{|c|}{ SPD ${ }^{\mathrm{TM}}$ era } & $\begin{array}{c}\text { Globalization } \\
\text { era }\end{array}$ \\
\hline $\begin{array}{l}\text { Total peer-reviewed } \\
\text { papers published }\end{array}$ & 0 & 2 & 16 & 37 & 25 & 31 & 65 & 172 \\
\hline $\begin{array}{l}\text { Total papers } \\
\text { published in ISI } \\
\text { database journals }\end{array}$ & 0 & 0 & 10 & 19 & 17 & 14 & 30 & 124 \\
\hline $\begin{array}{l}\text { Average impact } \\
\text { factor of journals* }\end{array}$ & 0 & 0 & 0.43 & 0.44 & 0.78 & 0.30 & 0.49 & 1.30 \\
\hline
\end{tabular}

$*$ Non-ISI journals are coded as having an impact factor of 0 .

"independent homelands," the subsections of South Africa that had been designated "black" areas.

Having been set up with domestic energy sufficiency as goal, Sasol had little interest in producing for a global market at this time; its international contact was limited to sourcing the expertise that it lacked. And within South Africa, there were no other firms that might have been interested in its technologySasol was a state-sponsored monopoly. Since Sasol did not stand to gain from disclosing its capabilities, it was relying on secrecy to protect its IP and disclosing it only in a haphazard way.

\section{B. Local Experimentation: The Secunda Era ( \pm 1976 -1985)}

From the mid-1960s the National Party government had secretly planned to dramatically expand Sasol's capacity, and by the 1970 s the global oil crisis and the deepening of antiApartheid activism provided the government with the justification it needed for developing Sasol II (in 1974) and Sasol III (in 1978) in the newly proclaimed town, Secunda.

Essentially, Sasol II and III were vastly scaled-up versions of previously developed technologies. Most learning during this phase consisted of incremental learning-by-doing in the course of production, rather than significant technological advances. For example, construction of Sasol III took only three years (compared to the 5 years or 100 million hours of work required for Sasol II) as a result of leveraging the learning curve of Sasol II. Managing the inadequate human resource base proved to be a significant challenge: In 1978, productivity at Sasol I dropped by $8.6 \%$ through the combined effects of the loss of expertise to Sasol II and demotivation of the remaining workforce. By the end of 1983, the cost of training to restore the corporation to full technical and operational capacity was expected to exceed R63m, representing almost $5 \%$ of the annual turnover for that year [38].

Sasol II and III placed substantial demands on Sasol-a type of "crisis construction" [5] that resulted in extensive organizational learning. But whereas internationalization played a central role in the crisis construction and learning process documented by Kim, the crisis prompting Sasol's learning was a deepening local orientation with the consolidation rather than upgrading of capabilities. For example, research was increasingly focused on plant optimization. Because technology development projects tend to have long timeframes, and a number of initiatives were ongoing, the cost of adopting a local focus only became clear in the next era, when the anti-Apartheid struggle was at its most violent, and the world responded by limiting international contact.

Around the mid-1970s, Sasol started to formally publicize its newly developed knowledge. The emphasis at the time on the replication rather than creation of technologies, and the fact that the start of the process of formally sharing IP does not coincide with a period of great technological advances, suggests that the main driver for formalizing IP was not technological. Much as the growing awareness of the benefits of formal methods of IP protection was triggered through the example and participation of foreigners, it mainly reflected local experimentation by Sasol and is similar to the process documented for the case of another developing country, Brazil [27]. Although pursuing more formal methods of IP protection did not realize any substantial business benefits for Sasol, the mainly domestic focus of patenting and the small number of patents involved meant that the costs of this strategy were equally contained.

A total of 53 papers were published in journals with an average impact factor of 0.44 (see Table II), and 31 patents were filed over the 10-year period (Fig. 1). About half of the patents were also filed abroad (mainly Europe, although in certain cases also North America and Australia), and research was published equally in local and international outlets. Publications in international outlets tend to reflect collaborations with foreign partners, and indicate the dominance of those partners in determining the publication strategy. For example, one of Sasol's first journal publications was written in 1976 by German researchers Dressler and Uhde and appeared in Fette, Seifen, Anstrichm. In all, collaborations with foreign partners, mainly firms from the USA and Germany, generated ten papers.

As regards patenting, the increasing anti-Apartheid sentiment and the threats of disinvestment and economic isolation meant that the benefits of international patenting were limited. At a time when competitors such as Shell, Exxon, and BP were very active in developing and patenting their own FT technology, Sasol suffered from global censure, without the possibility of exporting technology through licensing or accessing foreign markets. The example of foreigners was an important reason for the growing awareness of IPP at Sasol, but there was still no underlying business strategy for why it was formalizing IP. For example, the location of patenting activities cannot be ascribed to a specific strategy, either in terms of access to markets or blocking competitors. Close association with German firm Lurgi 

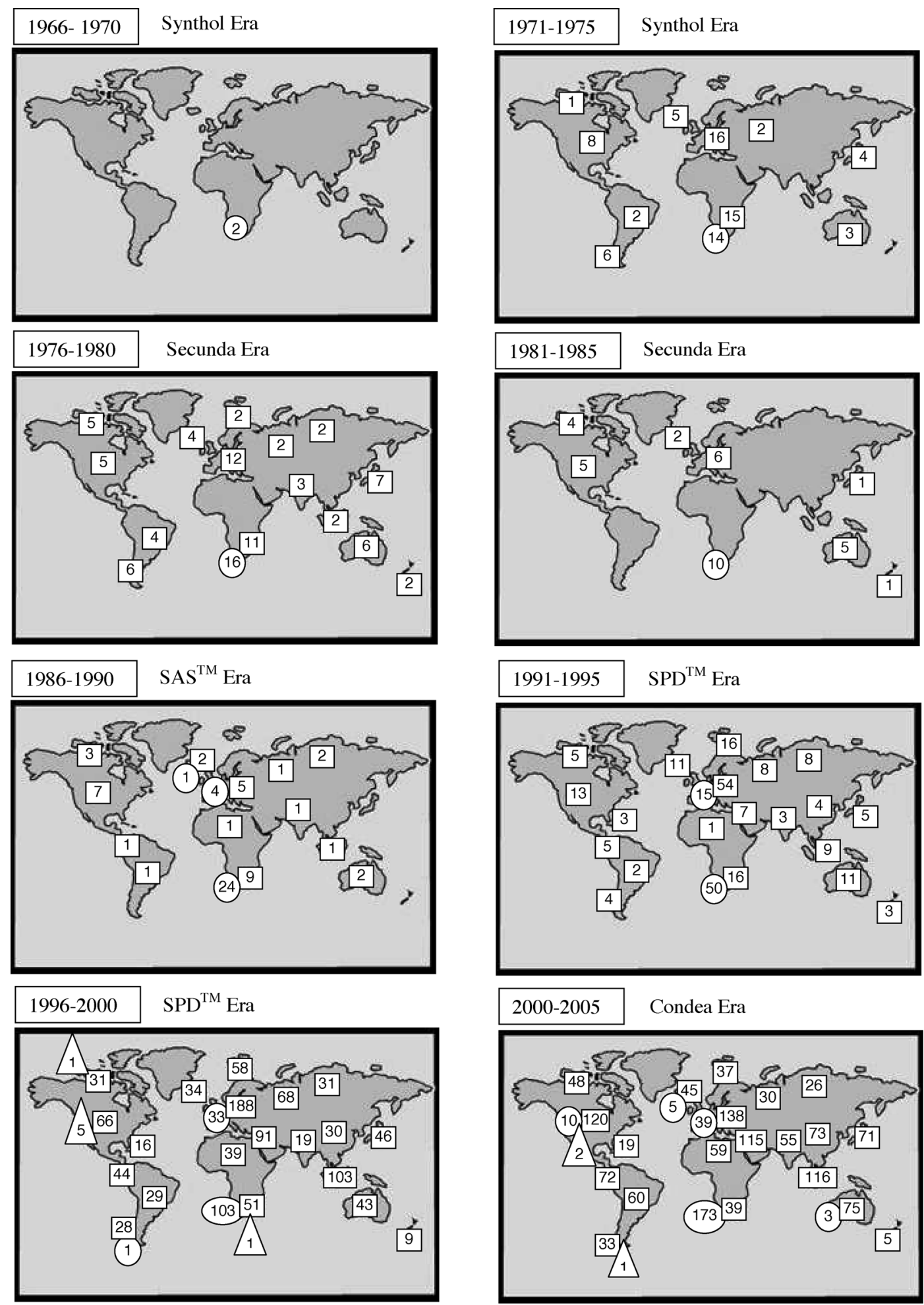

2000-2005 Condea Era

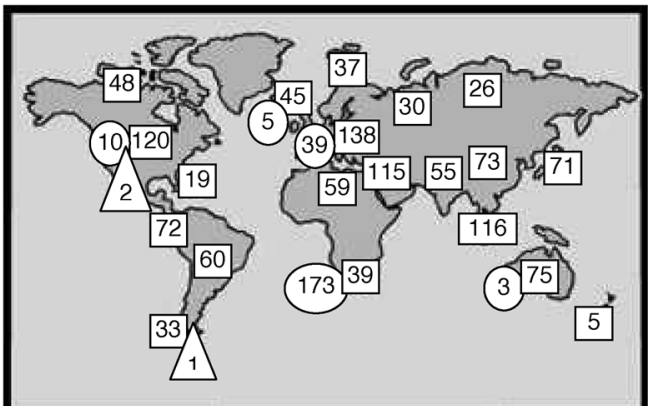

Fig. 1. Global distribution of Sasol-filed patent specifications. $\bigcirc$ : Original filing; $\square$ : re-filing; $\triangle$ : original not filed in country of invention. 
that developed gasification technology together with Sasol (in the Sasol-Lurgi Joint Venture) accounts for some of the focus on Europe. The clutch of U.S. patents can be explained by the fact that in 1971 Sasol was contracted to advise a company in North Dakota on the gasification of lignite, but there are no apparent reasons for the Australian filings in the early years.

\section{Foreign Experimentation: The SAS Era ( $\pm 1986-1990)$}

In the late 1980s, a number of Sasol projects came to fruition. During this period Sasol commissioned the first commercial scale SAS (Sasol advanced Synthol) reactor that delivered 3500 bbl/day with lower capital cost, increased flexibility and lower operating costs [39]. Sasol also made great strides with anode coke produced from pitch and the production of better fuels and developed world-class polypropylene and propylene plants and an improved catalyst that led to a substantial increase in the production of hard wax.

In 1987, the increasingly defensive National Party government also decided to further expand the fuel self-sufficiency of South Africa by developing Mossgas, a natural gas exploration and conversion project, like Sasol based on FT technology. Until the creation of Mossgas, there were no other South African firms active in the petrochemical industry, and there was no business need for local patents, so domestic patenting was nothing more than an opportunity for "safe" communication at low cost. However, Mossgas provided a local market for Sasol's know-how, as Sasol's Synthol technology was licensed to Mossgas for the conversion of natural gas into liquid fuels. Realizing the benefits of licensing, Sasol accelerated local patent filings (Fig. 1, 1986-1990).

Internationally, Sasol was maturing into a company that was technologically advanced enough to both contribute to and benefit from extensive interaction with other researchers in its field. Although Sasol increasingly invested in in-house technology development [40], it was at the same time involved in a number of ongoing initiatives for which access to foreign expertise was essential. For example, Sasol had leveraged its relationship with Badger/Raytheon in the United States for the development of Sasol fixed fluidized-bed (SFFB) reactors, and, ultimately, the commercial development of the HTFT SAS reactors [41]. However, 1986 marks the beginning of official international economic sanctions against South Africa, accompanied by an academic boycott. Foreigners risked global censure and worse for continuing economic and intellectual engagement with South African firms. This presented a serious threat to Sasol.

Sasol's potential exclusion from research networks because of a lack of political legitimacy prompted the firm to start thinking strategically about IPP. There was a deliberate decision to target specific technologies for patenting, mostly in order to counter the wave of patents from Shell, Exxon, and others. This was motivated, at least in part, by fierce pride in the achievements of the coterie of researchers, and their desire to regain perceived technological lost ground. Sasol's leading researcher in the coal-to-fuels technology, Dr. Mark Dry, published a number of papers and handbook chapters on the Sasol FT process.
These chapters would become synonymous with Dr. Dry and promoted Sasol's image as a leader in this field around the world. However, Sasol lacked a deep understanding of how to manage its IP. For example, a clutch of patents (of which Dr. Dry was a coinventor) was filed in an inordinate number of countries (30 or more) during this period. One patent-that has to date only received four citations and two self-citations and is clearly not a core patent-was filed in 46 countries. The broad country filing strategy was a result of letting scientists make decisions on the scope of patenting without the input of business people.

Oftentimes, poor patent drafting created challenges for subsequent patent applications because of unnecessary communication of certain elements. Whereas sound-patenting practice recommends limiting the degree of detail to cover no more than the scope of the invention, a number of the Sasol patents from this era generously described the entire process in detail and then only claimed one very specific aspect of the technology. While this form of broad documentation does in itself create prior art, thereby preventing others from patenting, it does not guarantee freedom to operate or offer the exclusive right to license. In short, although Sasol's actions demonstrate an increasing awareness of the value of IP, IP management was still done randomly and reflected the research interests of the scientists more than the business strategy. In addition, Sasol was initially quite naiveassuming that if something is not disclosed, it is automatically a classified trade secret. Thus, the additional security that should be in place to support the decision not to disclose a technology (e.g., version and copy controls of the document) was typically absent.

In this era, Sasol published in journals with noticeably higher impact factors than before (Table II) even though it seems likely that Sasol's capability development during this period was limited. The political context made it virtually impossible to enter into official academic international collaborations, and even longstanding collaborators, like the U.S. firm Raytheon, retreated from the relationship. In the next period [the local governance, or slurry phase distillate (SPD) era] the average impact factor of publications in which Sasol published dropped sharply, while the patenting activity also remained somewhat lower than what could be expected. The spike in publishing in higher impact factor journals likely reflects something other than increasing technical expertise.

Its publication strategy during the politically volatile $1980 \mathrm{~s}$ reflects an attempt by Sasol to increase its perceived technological legitimacy among its peers. Sasol's response highlights the importance of scientific publication as a signaling device: By disclosing some of its most interesting research results to the research community, Sasol was able to remain a participant in that community. Although the number of official collaborations reduced sharply, Sasol was able to maintain informal relationships by increasing its visibility in the formal networks of knowledge creation. Patenting can serve a similar signaling purpose, but it seems that Sasol at that time, and given its experiences with Dr. Dry internationally and Mossgas locally, associated patenting more closely with a drive to appropriate direct financial benefits from new technology. Given the constraints Sasol faced in 
international trade, scientific publication was chosen as the most effective way of communicating its technological capabilities.

\section{Local Governance: SPD Era ( $\pm 1991-2000)$}

After Nelson Mandela's release from prison in 1990, economic sanctions and the academic boycott were lifted, and South African firms were free to resume international contact. For Sasol, the 1990s heralded a change in strategy with the announcement of diversification into higher value chemicals [40]. Both technological diversification [42], [43] and the migration into higher value products [35], [36], [44] are associated with technologically more mature companies, and the Sasol trajectory is therefore typical.

A study of patenting in Brazil documents that developing country firms often experiment with patenting by filing domestic patents, while filing patents at the United States Patent and Trademark Office (USPTO) serve to signal increasing capability [27]. Sasol seems to have followed a similar pattern. The patenting that took place at Sasol prior to 1997 was done in a fairly desultory fashion. Sasol's initial filing of patents, particularly during the period of foreign disinvestment, was basically regarded as a cost-effective form of communicating expertise since Sasol held a clear local monopoly. As shown in Fig. 2, there is a gradual upward trend in the number of patents filed by Sasol until 1997, although the negative effect of political isolation on patenting is apparent. A positive step change in the propensity to patent follows the formation of the IP group in 1997. (The patent applications, which were listed as pending during 2004 or 2005, are not included in the data set, resulting in a lower count of patents for the years 2004 and 2005).

Until 1997, when Sasol introduced a formal IP function, patent applications were handled on an ad hoc basis by the Company Secretary and an external patent attorney. When Sasol started the process of actively managing the making public its technology, it adopted a strategy of encouraging Sasol scientists and engineers to pursue careers as patent attorneys, enabling patent attorneys to be familiar with the technology as well as having the required legal qualifications.

One of the reasons for the formation of an IP function within Sasol was to effectively deal with the threat of Exxon's aggressive patenting strategy to Sasol's freedom to operate. At the time, Exxon's annual patent applications were an order of magnitude greater than those of Sasol. Based on the number of patents filed per year in the period 2000-2005, it was estimated that Exxon's IP budget was in the order of US \$40-50 million-compared to an amount of about US \$50 million for Sasol's operating expense over that period.

Second, as the maintenance costs (like defending patents and renewal costs) for the large number of foreign patents started to become evident, Sasol realized that patenting is not free. In order to both track the trends in competitor patenting and manage the increasing costs of in-house patent applications, it was essential that a formal IP function be created.

The initial focus in the new IP management process was around the decision whether to patent or publish, or not. The fundamental question in managing IP is whether publicly sharing information about a technology is potentially beneficial and thus necessary (see Daizadeh [45] for a decision tree). However, for long this question did not feature as a priority among the questions that the IP review team asked. Often the decision to disclose or not was based more on the costs involved in patenting, rather than on the strategic importance of communicating the technology. Moreover, the consequences of decisions were not always thought through. Thus, the decision not to patent did not necessarily result in an invention being written up as a trade secret with the necessary controls, and if the decision was to patent, there was often an assumed permission to publish the work in scientific publications after the patents were public.

Initially, there was huge resistance from the scientists and engineers at having to become familiar with the "legalese" involved in patenting. They resented the perceived interference of the patent attorneys in their research and did not understand the implications of offensive and defensive patent strategies for their technology development. Gradually, through intensive workshop sessions, an awareness of IP began to take hold among the research team and they embraced the concepts of inventiveness and novelty in defining their technological innovations. While presentations at conferences (particularly international events) were encouraged as a means of demonstrating Sasol's expertise, strict governance was placed on the content of these presentations, and each slide had to be sanctioned by the IP manager before publication.

Fig. 3 demonstrates a change in the propensity to publish in scientific journals following the formation of the IP function in 1997. However, in terms of average journal impact, the data (Fig. 4) appear fairly scattered and there is no clear evidence of benefits from the introduction of the IP group. To the extent that an understanding of formal IP is a separate process from technology accumulation, this is not surprising. The formalization of the IP function would have created an awareness of the value of formalizing IP, but would not have been able to influence the scientific quality of the research.

A key consideration when considering patenting is the value that is captured by the firm in exchange for dissemination of knowledge. We use forward citations of Sasol-filed patents as an indication of value captured and analyze them following the methodology of Mowery et al. [46], where patents that were more heavily cited are interpreted as being more important sources of ensuing inventive activity. Fig. 4 shows all the Sasol patent applications that received at least one forward citation prior to 2005. There is a clear change in the slope of the line after the introduction of a formal IP function. (The lower count for 2004 and 2005 can be ascribed to a truncation bias as a result of which later patents will have fewer citations.) A Bonferroni pairwise test (Table III) confirms that the SPD era and globalization events are statistically significantly different to the previous eras in terms of number of forward citations. It has already been shown that the number of patents also increased dramatically in the latter two eras (Fig. 2). To demonstrate that the increase in citations was not merely due to an increase in patenting, Fig. 5 shows that although the number of cited patents does increase with a greater propensity to patent, there is also an increase in the percentage of cited patents post 1990. 


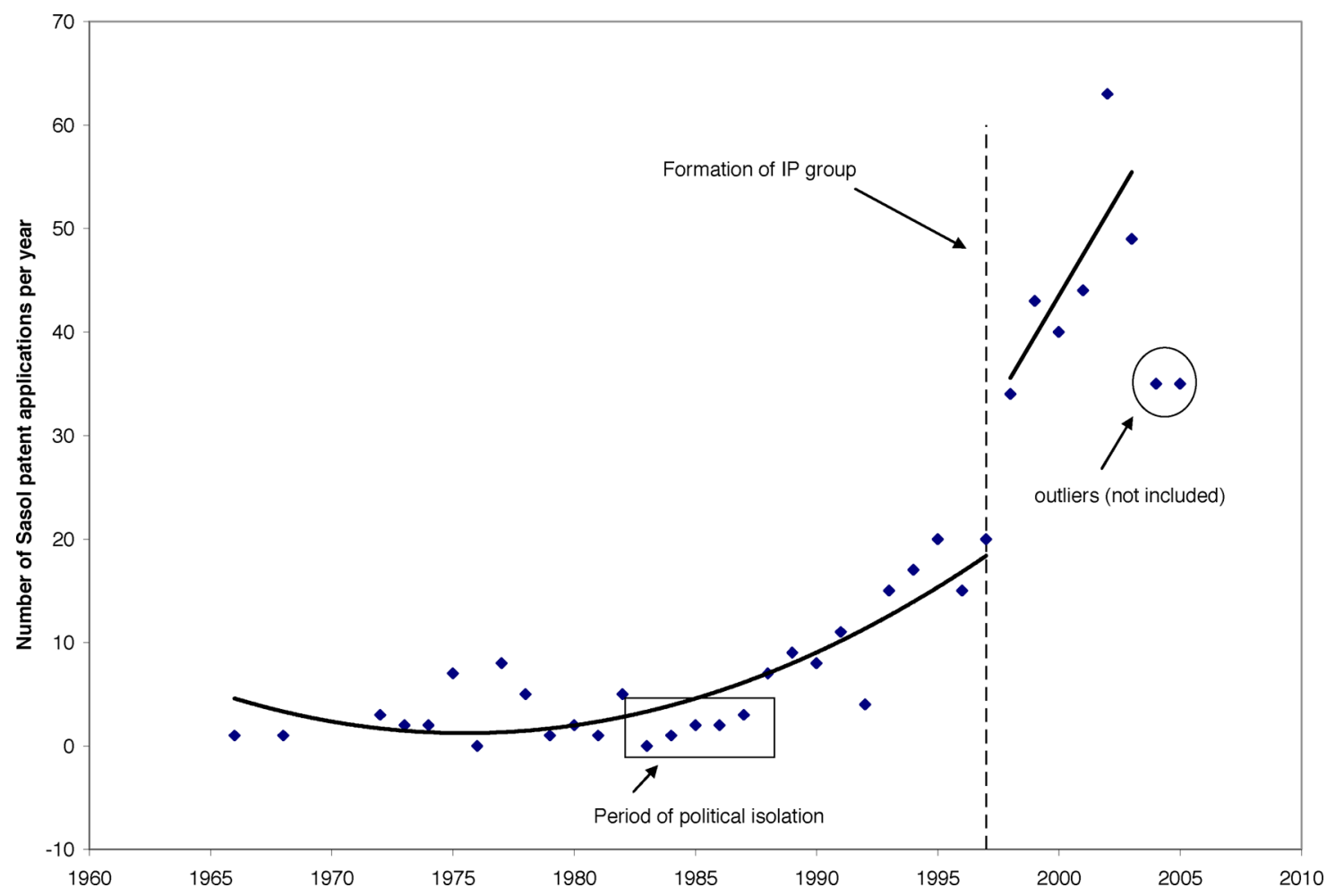

Fig. 2. Variation in number of patents filed by Sasol employees during 1966-2005.

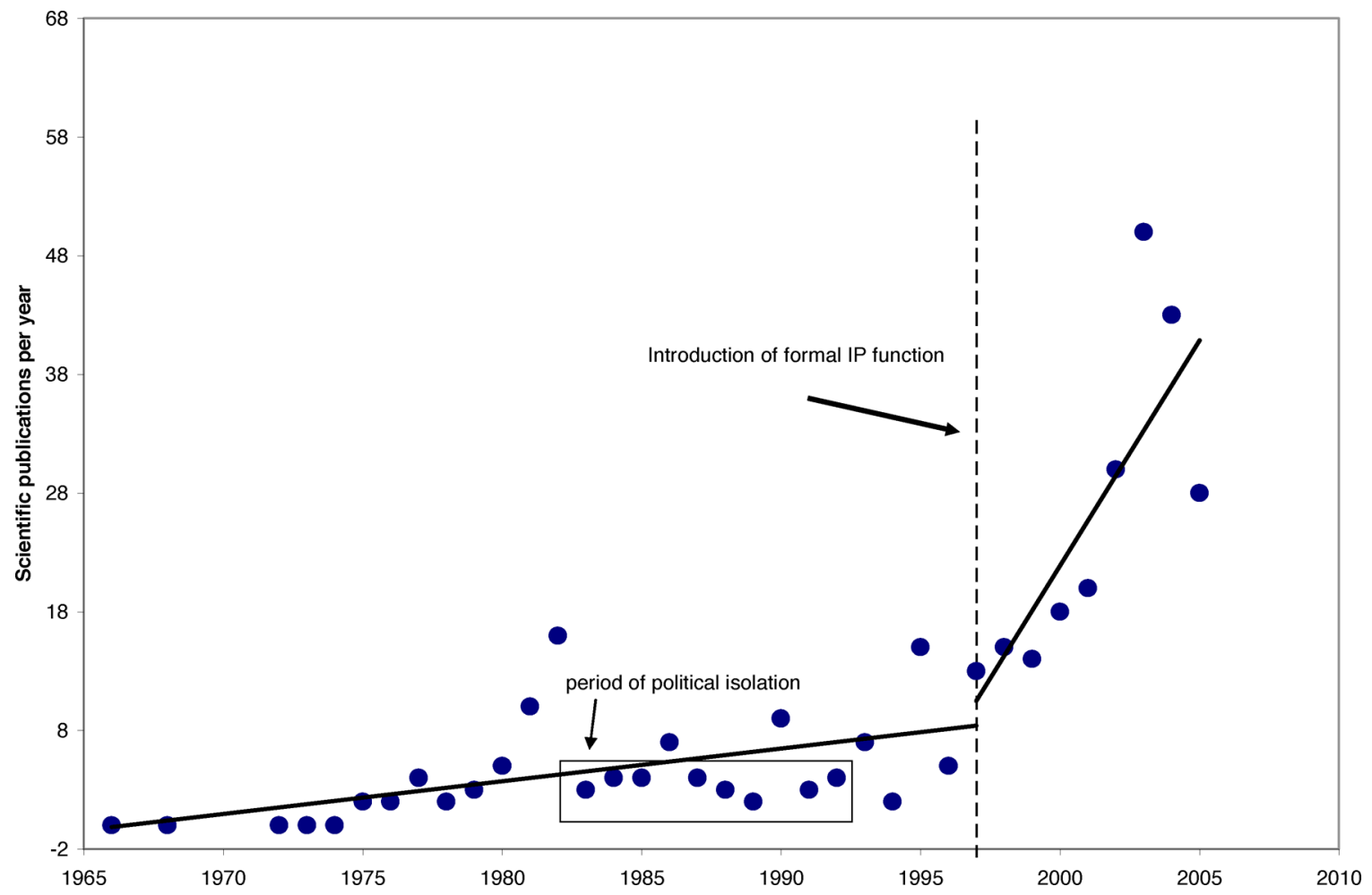

Fig. 3. Variation in number of scientific publications by Sasol from 1966 to 2005. 


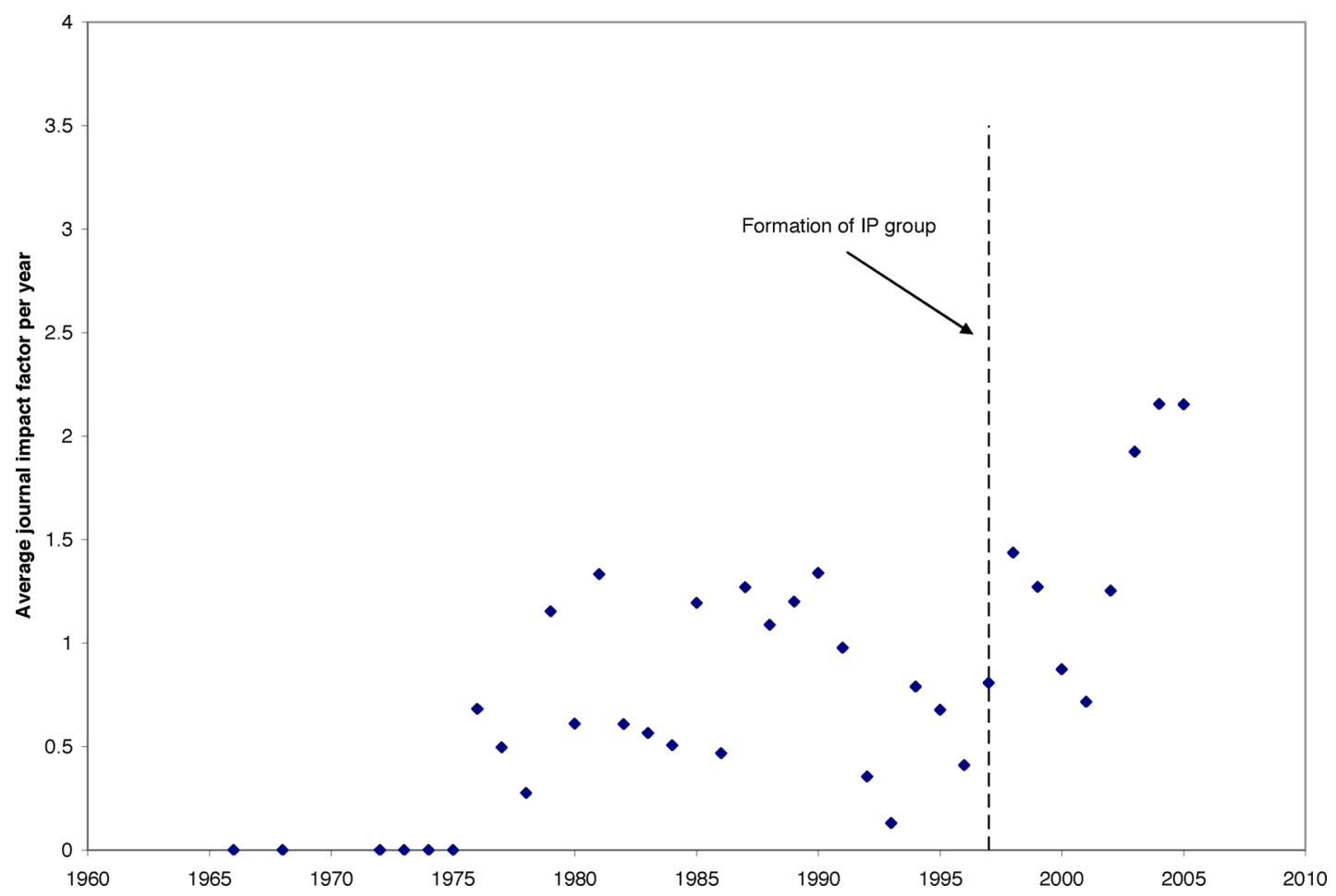

Fig. 4. Variation in average journal impact factor.

TABLE III

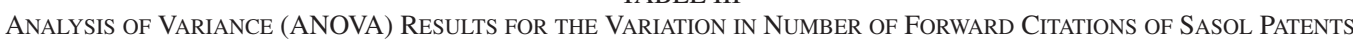

\begin{tabular}{|c|c|c|c|c|c|c|}
\hline \multirow[b]{2}{*}{ Response } & \multirow[b]{2}{*}{ DF } & \multirow[b]{2}{*}{$\mathrm{p}$} & \multirow[b]{2}{*}{ F-ratio } & \multirow[b]{2}{*}{ MSE } & \multicolumn{2}{|c|}{ Bonferroni pairwise test* } \\
\hline & & & & & Group A & Group B \\
\hline $\begin{array}{l}\text { Number of } \\
\text { forward citations }\end{array}$ & 172 & 0.00286 & 7.56 & 5.84 & $\begin{array}{l}\text { Secunda } \\
\text { SAS }\end{array}$ & $\begin{array}{l}\text { SPD }^{\mathrm{TM}} \\
\text { Globalization }\end{array}$ \\
\hline
\end{tabular}

*Eras in Group A were not statistically different to each other, but were found to be significantly different from those in Group B and vice versa.

During this era, Sasol developed local mechanisms to formalize the governance of IP. This allowed Sasol to better control some of the costs associated with IP management, and improved the quality of communication by developing an awareness of the purpose of IP management among researchers. But because Sasol was disclosing its IP on a more consistent basis than before, it was attracting the attention of its competitors in the developed world, and Sasol did not yet have the capacity to hold its own among some of the largest multinationals in the world.

\section{E. Global Governance: The Globalization Era ( $\pm 2001-2005)$}

In 2001, Sasol announced a new corporate vision statement, starting out with the desire to be a "respected global enterprise." As part of this strategy, in 2001, Sasol acquired the chemical business of the German firm RWE-DEA, Condea, renaming it Sasol Chemie and thus gaining access to Condea's R\&D laboratories and patent portfolio. In addition to expanding its R\&D across the globe (see Table IV for the geographical location and technological specialization of Sasol's various R\&D laboratories), Sasol entered into formal collaborations with the universities of both Cape Town and Johannesburg in South Africa, and in 2002 also with universities in the Netherlands (Twente) and
Scotland (St. Andrew's). Sasol also established two research groups with mainly foreign members to develop (in Homogenous Catalysis) and strengthen (in Heterogeneous Catalysis) its research capacity.

Management at Sasol was using the book "Edison in the Boardroom" [47] as a learning text about how to optimally manage its IP. However, insight into the critical elements of IP management developed only gradually and through practicethere was extensive learning-by-doing about managing IP. The IP strategy of each technology area at Sasol emerged somewhat organically as patenting activities crystallized the requirements and shortcomings of the IP strategy. For example, publications were no longer guaranteed to follow patenting, with the business unit strategy guiding whether alternative forms of IP protection would be sought. Because trade secrets are notoriously difficult to police, and because of the greater international orientation and openness of Sasol, Sasol also decided to rely on secrecy only under exceptional circumstances. The conversation about whether and how to disclose intellectual assets became increasingly strategic.

Much as the first era in Sasol's history had served as an incubation period, allowing Sasol to assimilate transferred technology and evolve into a truly South African company, by 2005 
TABLE IV

GEOGRAPHICAL LOCATION AND TECHNOLOGICAL SPECIALIZATION OF R\&D LABORATORIES

\begin{tabular}{|ll|}
\hline Corporate R\&D & Sasolburg (South Africa) \\
& Twente (Netherlands) \\
& St Andrews (Scotland) \\
Sasol Oil & Sasolburg (South Africa) \\
& Cape Town (South Africa) \\
Merisol & Sasolburg (South Africa) \\
Sasol Olefin and Surfactants & Sasolburg (South Africa) \\
& Lake Charles (USA) \\
& Moers (Germany) \\
& Brunsbuttel (Germany) \\
& Marl (Germany) \\
& Paderno (Italy) \\
& St Andrews (Scotland) \\
Sasol Solvents & Sasolburg (South Africa) \\
& Moers (Germany) \\
Sasol Nitro & Sasolburg (South Africa) \\
Sasol Polymers & Modderfontein (South Africa) \\
Sasol Wax & Sasolburg (South Africa) \\
& Hamburg (Germany) \\
\hline
\end{tabular}

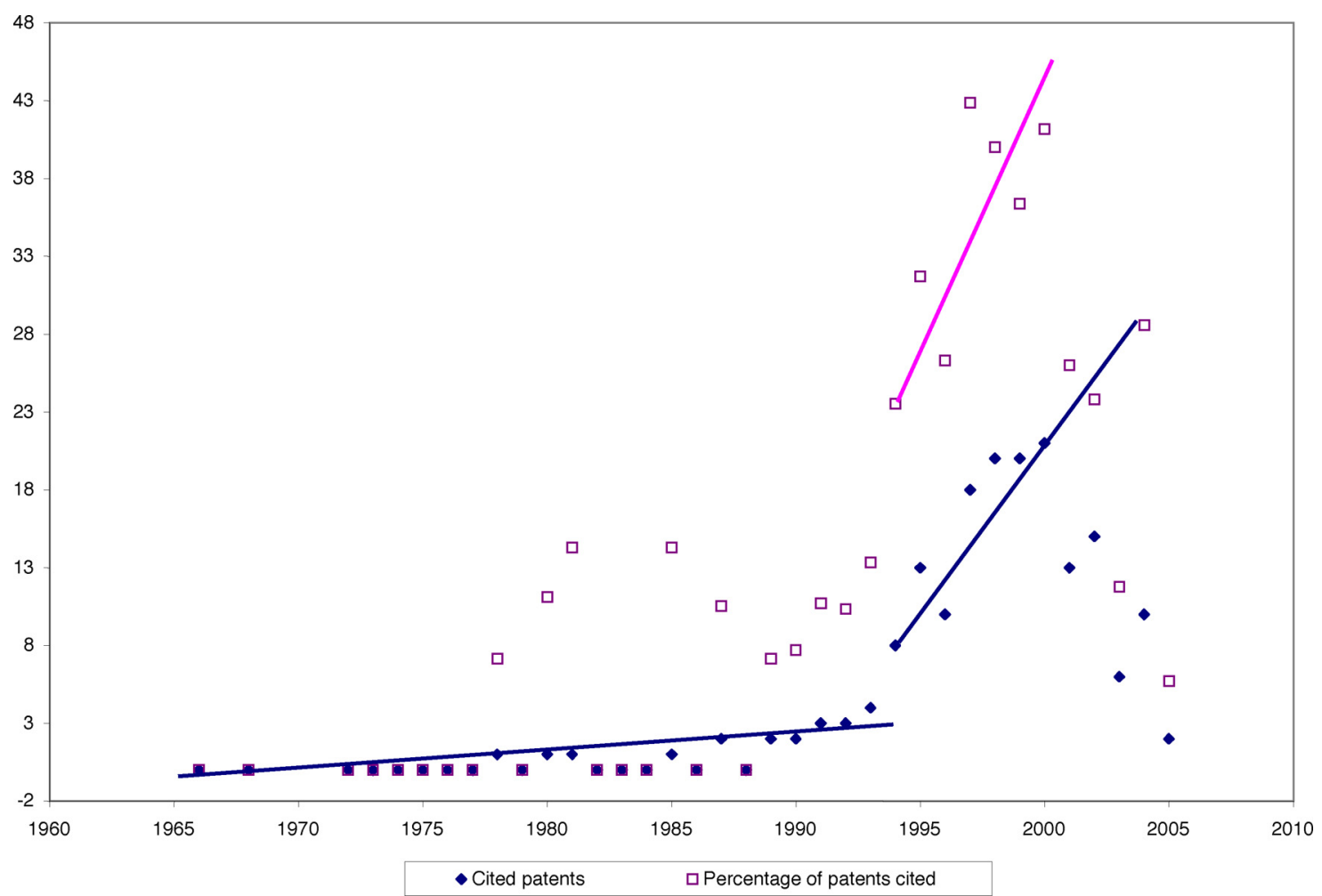

Fig. 5. Forward citations of Sasol-filed patents (1966-2005).

Sasol concluded an incubation period that heralded the start of its identity as a multinational firm. The firm had diversified its technological capability-base beyond the FT process by drawing on expertise from across the world, and the basic structure of its multinational organization (e.g., the global plants and R\&D departments) had been established. By the end of this era, Sasol was actively working to further expand operations, i.e., into China and Qatar.

Given that sharing IP always involves a tension between competition and cooperation, it is hardly surprising that Sasol started running into IP-related conflict with competitors. During the time that Sasol was developing its SPD technology, Shell was improving its fixed-bed cobalt catalyst technology for the conversion of gas to liquids. The parallel development pathways of these competing technologies often intersected in the patent arena, and a tense rivalry developed between Sasol and Shell that was often fought out on the European Patent Office (EPO) battleground. While the Sasol team had been relatively successful in defending its technological territory, having to endure tough litigation proceedings highlighted many shortcomings in 
filing strategy and claim drafting. Indeed, the costs of preparing for patent litigation and prosecution have at times proven to significantly outweigh any benefit that could possibly be derived from owning a granted patent. This points toward the importance of clarifying the purpose of selecting the patent route as a method of IP, because publication in a scientific journal can serve equally well in creating prior art, at virtually no cost. Where the immediate aim is to signal competence rather than to directly appropriate financial gain, it may be worth reducing the level of protection - and costs - of patenting.

In 2000, Sasol further refined its IP management process. Technology development timeframes are typically fairly long, yet the window of opportunity to exploit the associated competitive advantage is often comparatively short. Hence, Sasol defined one of the functions of the IP management team as advising on appropriate alternatives in securing access to technology. For instance, Sasol purchased a selection of patents from Energy International between the period of 1998 and 2004 and thereby rapidly expanded its FT technology offering without doing in-house research.

The SASOL/Chevron joint venture (JV) that was concluded in 2000 provided Sasol with valuable insight into the IP management process of another leading petrochemical country, and Sasol modeled a number of refinements on Chevron practices. First, the JV with Chevron required Sasol to sharpen its patenting strategy in the areas of overlap between the two firms, and this provided the impetus for certain areas to get to grips with the decisions surrounding patenting. In addition, Chevron served as model for the development of IP review teams to formally decide, per technology area, on the most appropriate vehicle for claiming IP (trade secret, patent, or scientific publication) in order to manage the business and technological risk associated with revealing scientific capabilities. Indeed, the advent of the IP Review Teams in 2000 heralded a more rigorous approach to patenting.

Specific country filing strategies were developed for different technology areas, chosen from a preselected list of markets, sources of feedstock, or location of synthetic fuel plants. The review teams have proven to be successful in competitor analysis and technology landscaping, increasing the agility of responses in terms of in-house filing strategies and opposition proceedings. In order to ensure alignment with the corporate strategy, an IP governance committee ratifies decisions taken by the review team. Subsequent changes further reflect the ongoing evolution of Sasol's IP strategy. For example, so-called "Deep-dive Specialists" and "Value-chain Coordinators" have been appointed to ensure that the patent portfolio has the desired balance between focused specialization and technology integration across process units.

\section{DISCUSSION}

Sasol's process of developing a well-functioning IP management strategy highlights a number of important points about how this process takes place. First, the capability to manage IP has to be actively developed; it is not a simple "by-product" of developing more sophisticated technologies. However, the two processes coevolve: The creation of more sophisticated technologies creates both an awareness of the potential benefits of IP and the greater desire and need to interact more extensively with other researchers who are active in the field. Second, it is important for firms to recognize that IPP involves more than directly appropriating own capabilities. Effective patentors have a nuanced sense of the costs and benefits associated with formal IP and specifically recognize the cooperation/competition tension that is triggered whenever IP is shared in a community. Finally, collaboration is central not only to the use, but also the development of an effective IP management strategy. Both patents and scientific publications provide credible evidence of the capabilities of a firm, largely because they are externally reviewed (by a patent examiner or a peer group). Because communicating IP can signal competence to the field, it is essential for a latecomer firm to ensure that it establishes relationships not only through its patenting and publications, but also in addition to those activities.

Although formal R\&D is typically seen as a relatively late development in the evolution of developing country firms [48], this research highlights the importance of supporting formal IP management strategies for all technology-based firms, also those from the developing world. It is clear that the capacity to manage IP evolves over time, but the study also suggests the need to formalize an IP management strategy and to review it on an ongoing basis in order to extract maximum value. In the Sasol case, a number of costly patenting mistakes could have been avoided had an IP strategy existed before any sharing of IP took place. In fact, the case of Sasol suggests that the formulation of an IP strategy should ideally take place before capabilities are revealed. This strategy should be informed jointly by the indigenous technological capability present at the time, as well as the governing business model, in consultation with a recognized authority on IP. Since it is unlikely that this competency would reside in-house at this early developmental stage, the services of an experienced patent attorney would be required.

Such assistance can help reduce the possibility of an ill-judged publication or patent and can (by communicating the appropriate level of novelty of a technology) help gains in credibility to occur concomitantly with organizational learning. It is highly likely that the IP strategy would dictate secrecy in areas where significant technology development is still required. This approach will also facilitate the introduction of a formal in-house IP function once the firm has developed sufficient capability to justify the associated costs. Thus, by strategically considering the reasons for sharing information about new intellectual property, as well as the timing thereof, firms can leverage their intellectual property both offensively and defensively.

\section{CONCLUSION}

Having a coherent IP strategy is one of the characteristics of MNCs, especially in chemical and related industries. Apart from the direct financial benefits that firms can realize through i.e., the licensing of patents, patents and scientific publications also act as signals of technical competence and legitimacy in the field. For developing country MNCs-coming from economically 
less successful regions — such "currency" is especially important to gain access to the relevant international knowledge networks.

This study offers a detailed case analysis of the leading R\&D firm of an important emerging economy, South Africa. Although the case suffers from the shortcomings typical of case study research, particularly a lack of generalizability, it manages to differentiate between narrow technological and IP management capability development. In doing so, it not only provides a nuanced perspective on how a latecomer firm has made the transition to a modern MNC, but also on the functioning of IPP.

\section{REFERENCES}

[1] A. S. Oddi, "The international patent system and third world development: Reality or Myth?" Duke Law Rev., vol. 5, pp. 831-878, 1987.

[2] S. K. Sell, "Intellectual property protection and antitrust in the developing world: Crisis, coercion, and choice," Int. Org., vol. 49, pp. 315-349, 1995.

[3] J. P. Murmann, Knowledge and Competitive Advantage: The Coevolution of Firms, Technology, and Institutions. Cambridge, U.K.: Cambridge Univ. Press, 2003

[4] M. Hobday, "The Republic of Korea: Catching up in large corporations," in Innovation in East Asia: The Challenge to Japan, M. Hobday, Ed. Aldershot: Edward Elgar, 1995, pp. 51-94.

[5] L. Kim, "Crisis construction and organizational learning: Capability building in catching-up at Hyundai motor corporation," Org. Sci., vol. 9, pp. 506-521, 1998.

[6] M. Lautier, "The international development of the Korean automobile industry," in Going Multinational: The Korean Experience of Direct Investment, F. Sachwald, Ed. $\quad$ London, U.K.: Routledge, 2001, pp. 207273.

[7] K.-R. Lee, "Technological learning and entries of user firms for capital growth in Korea," in Technology, Learning, \& Innovation, L. Kim and R. R. Nelson, Eds. Cambridge, U.K.: Cambridge Univ. Press, 2000, pp. 170-192.

[8] K.-R. Lee, "Technological catching-up through overseas direct investment: Samsung's camera business," in Going Multinational: The Korean Experience of Direct Investment, F. Sachwald, Ed. London, U.K.: Routledge, 2001, pp. 275-314.

[9] S. Perrin, "The internationalization of Korean electronics firms: Domestic rivalry and tariff-jumping," in Going Multinational: The Korean Experience of Direct Investment, F. Sachwald, Ed. London, U.K.: Routledge, 2001, pp. 167-206.

[10] G. Dutrénit, "Instability of the technology strategy and building of the first strategic capabilities in a large Mexican firm," Int. J. Technol. Manage., vol. 36, pp. 43-61, 2006.

[11] P. N. Figueiredo, "Learning, capability accumulation and firms differences: Evidence from latecomer steel," Ind. Corp. Change, vol. 12 pp. 607-643, 2003.

[12] P. N. Figueiredo, "Industrial policy changes and firm-level technological capability development: Evidence from Northern Brazil," World Develop., vol. 36 , pp. $55-88,2008$.

[13] D. de Solla Price, "Is technology historically independent of science? A study in statistical historiography," Technol. Cult., vol. 6, pp. 553-568, 1965.

[14] A. T. Bernardes and E. da Motta e Albuquerque, "Cross-over, thresholds, and interactions between science and technology: Lessons for lessdeveloped countries," Res. Policy, vol. 32, pp. 865-885, 2003.

[15] O. Granstrand, "Innovation and intellectual property rights," in The $O x$ ford Handbook of Innovation, J. Fagerberg, D. C. Mowery, and R. R. Nelson, Eds. $\quad$ Oxford, U.K./New York: Oxford Univ. Press, 2004, pp. 266290.

[16] J. Lerner, "150 years of patent protection," Amer. Econ. Rev., vol. 92, pp. 221-225, 2002.

[17] F. Machlup and E. Penrose, "The patent controversy in the nineteenth century," J. Econ. Hist., vol. 10, pp. 1-29, 1950.

[18] R. Mazzoleni and R. R. Nelson, "The benefits and costs of strong patent protection: A contribution to the current debate," Res. Policy, vol. 27, pp. 273-284, 1998.

[19] R. C. Levin, A. K. Klevorick, R. R. Nelson, and S. G. Winter, "Appropriating the returns from industrial research and development," Brookings Papers Econ. Activity, vol. 3, pp. 783-820, 1987.
[20] B. H. Hall and R. H. Ziedonis, "The patent paradox revisited: An empirical study of patenting in the U.S. semiconductor industry, 1979-1995," Rand J. Econ., vol. 32, pp. 101-128, 2001.

[21] J. Schmookler, "The utility of patent statistics," J. Patent Off. Soc., vol. 34, pp. 407-412, 1953

[22] W. M. Cohen, R. R. Nelson, and J. P. Walsh, "Protecting their intellectual assets: Appropriability conditions and why U.S. manufacturing, firms patent (or not)," NBER Working Papers, vol. 7552, pp. 1-31, 2000.

[23] M. Reitzig, "The private values of 'thickets' and 'fences': Towards an updated picture of the use of patents across industries," Econ. Innov. $N$. Technol., vol. 13, pp. 457-476, 2004.

[24] D. Hicks, "Published papers, tacit competencies and corporate management of public/private character of knowledge," Ind. Corp. Change, vol. 4, pp. 401-424, 1995.

[25] P. Muller and J. Pénin, "Why do firms disclose knowledge and how does it matter?" J. Evol. Econ., vol. 16, pp. 85-108, 2006.

[26] S. Lhuillery, "Voluntary technological disclosure as an efficient knowledge management device: An empirical study," Econ. Innov. N. Technol., vol. 15, pp. 465-491, 2006.

[27] E. da Motta e Albuquerque, "Domestic patents and developing countries: arguments for their study and data from Brazil (1980-1995)," Res. Policy, vol. 29, pp. 1047-1060, 2000.

[28] World Investment Report: Transnational Corporations and the Internationalization of $R \& D$. New York/Geneva: United Nations/United Nations Council for Trade and Development, 2005.

[29] E. Mansfield, "Patents and innovation: An empirical study," Manage. Sci., vol. 32, pp. 173-181, 1986.

[30] D. Harhoff, F. M. Scherer, and K. Vopel, "Citations, family size, opposition and the value of patents," Res. Policy, vol. 32, pp. 1343-1363, 2003.

[31] K. A. Borokhovich, R. J. Bricker, and B. J. Simkins, "An analysis of finance journal impact factors," J. Finance, vol. 55, pp. 1457-1469, 2000.

[32] D. Fok and P. H. Franses, "Modelling the diffusion of scientific publications," J. Econometrics, vol. 139, pp. 376-390, 2007.

[33] D. Hicks, "Limitations of co-citation analysis as a tool for science policy," Soc. Stud. Sci., vol. 17, pp. 295-316, 1987.

[34] P. O. Seglen, "Why the impact factor of journals should not be used for evaluating research," Brit. Med. J., vol. 314, pp. 498-502, 1997.

[35] F. Sachwald, Going Multinational: The Korean Experience of Direct Investment. London, U.K.: Routledge, 2001.

[36] L. Kim and R. R. Nelson, Technology, Learning, \& Innovation. Cambridge, U.K.: Cambridge Univ. Press, 2000.

[37] Annual Report, South African Coal, Oil and Gas Corporation Limited, Sasolburg, 1957.

[38] Annual Report, South African Coal, Oil and Gas Corporation Limited, Sasolburg, 1979.

[39] A. P. Steynberg and M. E. Dry, Fischer-Tropsch Technology. Amsterdam, The Netherlands: Elsevier, 2004.

[40] Annual Report, South African Coal, Oil and Gas Corporation Limited, Sasolburg, 1990.

[41] J. Collings, Mind Over Matter: The Sasol Story, a Half Century of Technological Innovation. Johannesburg, SA: Sasol, 2002.

[42] J. Cantwell, Technological Innovation and Multinational Corporations. Oxford, U.K.: Basil Blackwell, 1989.

[43] O. Granstrand and S. Sjölander, "Managing innovation in multitechnology corporations," Res. Policy, vol. 19, pp. 35-60, 1990.

[44] S. Lall, "What 'competitiveness' is and why it is important," in Competitiveness, Technology, and Skills, S. Lall, Ed. Cheltenham, U.K.: Edward Elgar, 2001, pp. 1-30.

[45] I. Daizadeh, D. Miller, A. Glowalla, M. Leamer, R. Nandi, and C. I. Numark, "A general approach for determining when to patent, publish, or protect information as a trade secret," Nature Biotechnol., vol. 20, pp. 1053-1054, 2002.

[46] D. C. Mowery, J. E. Oxley, and B. S. Silverman, "The two faces of partnerspecific absorptive capacity: Learning and cospecialization in strategic alliances," in Cooperative Strategies and Alliances, F. J. Contractor and P. Lorange, Eds. Oxford, U.K.: Elsevier, 2002, pp. 291-319.

[47] J. L. Davis and S. S. Harrison, Edison in the Boardroom: How Leading Companies Realize Value From Their Intellectual Assets. Hoboken, NJ: Wiley, 2001.

[48] H. Pack, "Research and development in the industrial development process," in Technology, Learning, and Innovation, L. Kim and R. R. Nelson, Eds. Cambridge, U.K.: Cambridge Univ. Press, 2000, pp. 69-94.

[49] L. P. Dancuart and A. P. Steynberg, "Fischer-Tropsch based GTL technology: A new process?" in ACS Nat. Meet., Anaheim, CA, 2004, pp. 1-17. 


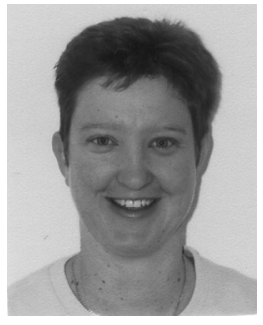

Tracy Bromfield received the Ph.D. degree in chemistry from the University of Witwatersrand, Johannesburg, South Africa, and MBA degree from the Gordon Institute of Business Science, University of Pretoria, Sandton, South Africa, in 2008.

She is currently the Manager of Applied Research at Sasol Technology R\&D, Sasolburg, South Africa. During her MBA she did research on the joint processes of technology accumulation and learning to manage intellectual property in a developing country firm.

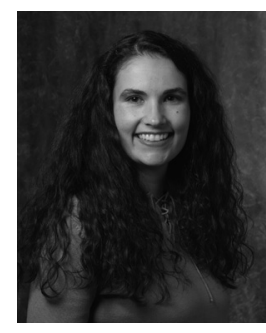

Helena Barnard received the Ph.D. degree in management from Rutgers University, Newark, NJ.

During her Ph.D. studies, she was involved in research on how developing country firms use foreign direct investment (FDI) to the developed world as a mechanism for upgrading. She has published amongst others in Research Policy and the International Journal of Technology Management. She is currently based at the Gordon Institute of Business Science, University of Pretoria, South Africa, where she continues her research on the effect of local excellence and foreign connections in the learning and upgrading of developing countries. 